\title{
Planform characteristics and development of inter- channel wetlands in a gravel-bed anastomosing river, Maqu Reach of the Upper Yellow River
}

\author{
LIU Boyi ${ }^{1,2}$, "WANG Suiji ${ }^{1,2}$ \\ 1. Key Laboratory of Water Cycle and Related Land Surface Processes, Institute of Geographic Sciences and \\ Natural Resources Research, CAS, Beijing 100101, China; \\ 2. College of Resources and Environment, University of Chinese Academy of Sciences, Beijing 100049, China
}

\begin{abstract}
Both interchannel wetlands and multi-channels are crucial geomorphologic units in an anastomosing river system. Planform characteristics and development of interchannel wetlands and multi-channels control the characteristics of anastomosing rivers. To understand the role that interchannel wetlands play in the development of anastomosing rivers, a study was conducted on the Maqu Reach of the Upper Yellow River (MRUYR), a gravel-bed anastomosing river characterized by highly developed interchannel wetlands and anabranches. Geomorphologic units in the studied reach were extracted from high resolution satellite imagery in Google Earth. The size distributions of interchannel wetlands and interchannel wetland clusters (IWCs), a special combination of interchannel wetlands and anabranches, were investigated. Geomorphologic parameters, including the ratio of interchannel wetland area to IWC area $(P)$, shoreline density $\left(D_{1}\right)$, and node density $\left(D_{n}\right)$ were used to analyze planform characteristics of IWCs and the development of multi-channels in the studied reach. The results suggest that small or middle sized interchannel wetlands and large or mega sized IWCs are more common at the study site. The area of IWC $\left(S_{u}\right)$ is highly correlated with other geomorphologic parameters. $P$ increases with increasing $S_{u}$, and the upper limit is about $80 \%$, which indicates that the development of interchannel wetlands and anabranches in the IWC is in the equilibrium stage. In contrast, $D_{1}$ and $D_{n}$ show a tendency to decrease with increasing $S_{u}$ due to diverse evolution processes in IWCs with different sizes. There are three main reasons leading to the formation of IWCs: varying stream power due to the meandering principal channel; development of the river corridor due to the weakening of geologic structure control; and high stability of interchannel wetlands due to conservation by shoreline vegetation.
\end{abstract}

Keywords: channel planform; gravel-bed anastomosing river; interchannel wetland; geomorphologic parameter; Yellow River

Received: 2017-06-02 Accepted: 2017-07-06

Foundation: National Natural Science Foundation of China, No.41571005, No.41271027

Author: Liu Boyi, Master Candidate, specialized in fluvial geomorphology. E-mail: liuby.14s@igsnrr.ac.cn

"Corresponding author: Wang Suiji, $\mathrm{PhD}$ and Associate Professor, specialized in fluvial geomorphology and fluvial sedimentology. E-mail: wangsj@igsnrr.ac.cn 


\section{Introduction}

An anastomosing river is composed of interconnected channels that enclose vegetated interchannel wetlands (fluvial islands) or floodbasins (Schumm, 1968; Miall, 1977; Rust, 1978; Smith and Smith, 1980; Makaske, 2001; Wang et al., 2005). Multi-channels network and vegetated interchannel wetlands are two fundamental components of anastomosing rivers. The multi-channel network in anastomosing rivers is significantly different from the single channel in straight or meandering rivers. Furthermore, stable interchannel wetlands in anastomosing rivers are different from the midchannel bars of braided rivers. Since anastomosing rivers were recognized as an independent river pattern, their sedimentary and hydraulic properties have been extensively studied (Wang and Ren, 1999; Yin et al., 2000; Makaske et al., 2002; Tabata and Hickin, 2003; Wang, 2003; Wang et al., 2004; Abbado et al., 2005; Makaske, 2009; Makaske et al., 2017). In addition, the formation and stability of the multi-channel network within anastomosing rivers has also been investigated (Miller, 1991; Wang et al., 2000; Makaske, 2001; Wang, 2002; 2004; Wang et al., 2005; Roze et al., 2012). Previous studies have suggested that avulsions, primarily driven by aggrading channels, form new channels in anastomosing rivers (Bryant et al., 1995; Jones and Schumm, 1999, Makaske, 2001). Meanwhile, frequent avulsions combined with relatively slowly abandoned old channels help maintain the multi-channel network (Makaske, 2001; Abbado et al., 2005).

Previous research on the planform of anastomosing rivers has focused on the need to distinguish anastomosing rivers from other river patterns. Parameters including sinuosity index, braiding index (Brice, 1964), braiding parameter (Rust, 1978), and braid-channel ratio (Friend and Sinha, 1993) have been used in the identification of anastomosing rivers. However, few of those parameters represent the most significant characteristics of anastomosing rivers: the highly developed multi-channels and vegetated interchannel wetlands. A likely reason for this neglect is the lack of high-precision data, which could be used to describe the planform characteristics of complex multi-channel network in anastomosing rivers.

Both interchannel wetlands and multi-channels are crucial geomorphologic units in anastomosing rivers. Planform characteristics and the development of interchannel wetlands and multi-channels control the behavior of anastomosing rivers. In recent papers on the planform characteristics of other multi-channel rivers, researchers extracted interchannel wetlands, bars, and channels using historical maps and aerial photos ( Hooke and Yorke, 2011; Belletti et al., 2015), then addressed their formation and evolution (Zanoni et al., 2008; Church and Rice, 2009; Wyrick and Kingeman, 2011; Mikuś et al., 2013; Picco et al., 2014). Multi-channel rivers essentially form in two ways: (1) splitting of diverted avulsive flow, leading to the formation of new channels on floodplains or interchannel wetlands (e.g., Wang et al., 2000; Makaske, 2001); and (2) formation of new interchannel wetlands due to stabilization of sand or gravel bars, causing the diversion of the former channel (Osterkamp, 1998; Gurnell et al., 2001). Clearly, the evolution of interchannel wetlands and multi-channels are highly connected.

The Maqu Reach of the Upper Yellow River (MRUYR) is comprised of a single channel and multi-channel subreaches that alternate among anastomosing, anabranching, meandering, and braided river patterns (Wang, 2008; Li et al., 2013a). Previous work has demonstrated that the valley setting, channel gradient, riparian vegetation development, regional hydrology and sediment load conditions, and tributary confluences influence channel planform 
transformations (Wang, 2008; Li et al., 2013a, 2013b; Yu et al., 2013, 2014). The development of interchannel wetlands and multi-channels in an anastomosing subreach exhibit spatial variety due to these channel planform transformations. Moreover, the gravel-bed anastomosing subreach along MRUYR is significantly different from other sand-bed anastomosing rivers; the interchannel wetlands and anabranches in this anastomosing subreach appear in the form of interchannel wetland clusters (IWCs), a special combination of interchannel wetlands and gravel-bed anabranches.

Therefore, this area is a good example and study site to investigate planform characteristics of gravel-bed anastomosing rivers. Geomorphologic units, including channels, interchannel wetlands, and IWCs, were extracted using high resolution Google Earth images. Then, the size distributions of interchannel wetlands and IWCs were investigated. Finally, geomorphologic parameters, including the ratio of interchannel wetland area to IWC area (Zanoni et al., 2008), shoreline density (Kidová et al., 2016), and node density (Bertoldi et al., 2009) were used to analyze the planform characteristics of IWCs and development of channels in the study area.

The purpose of this paper is to describe the planform characteristics of interchannel wetlands in the anastomosing MRUYR. A particular focus is the relationship between IWCs and development of the multi-channels in anastomosing rivers.

\section{Study area}

The study area is located in Maqu County in southwestern Gansu Province, a marginal area in the eastern Qinghai-Tibet Plateau (Qi and Li, 2008). It has a humid alpine climate; annual precipitation is about $564 \mathrm{~mm}$ and mean annual temperature is about $1.1^{\circ} \mathrm{C}$ (Chu et al., 2014). Based on landform variability, Maqu County can be divided into three regions, the north-western mountain, middle-southern hill, and eastern valley plain regions (Liu et al., 2012). The MRUYR lies in the eastern portion of the Animaqing (Anyemaqen) Mountains, where the river turns nearly $180^{\circ}$ in the 'U-shaped' form (Figure 1). This part of the river is about $270 \mathrm{~km}$ in length, from the entry location near Awancang Town in Maqu, to the exit in southwestern Maqu County. It consists of anastomosing, anabranching, meandering, and braided reaches (Wang, 2008; Li et al., 2013a). The particularly anastomosing reach is evident near Qihama and Cairima towns.

This study concentrates on the $65 \mathrm{~km}$ anastomosing reach with highly developed interchannel wetlands and multi-channel network, situated near Cairima and Qihama towns, which lies in the transitional area between the middle-southern hill and eastern valley plain regions. The land cover on the riversides and interchannel wetlands is clearly different. Alpine meadows cover most riverside areas (Jiang, 2008), while trees and shrubs grow on the interchannel wetlands (Chu et al., 2014). Sediment sizes are also different between riverside, interchannel wetlands, and channels. Riverside and interchannel wetlands are covered with fine sand sediment, while channels are mainly occupied by gravel, whose median grain size varies from $40 \mathrm{~mm}$ to $70 \mathrm{~mm}$ (Wang, 2008). The flow regime is dominated by precipitation and snow-ice meltwater. The discharge at the Maqu gauging station (1959-1989 and 2008-2013) usually reaches a maximum in July or September; the mean discharge in June and September is $1046.74 \mathrm{~m}^{3} / \mathrm{s}$ and $955.19 \mathrm{~m}^{3} / \mathrm{s}$, respectively. While an extreme flood event 


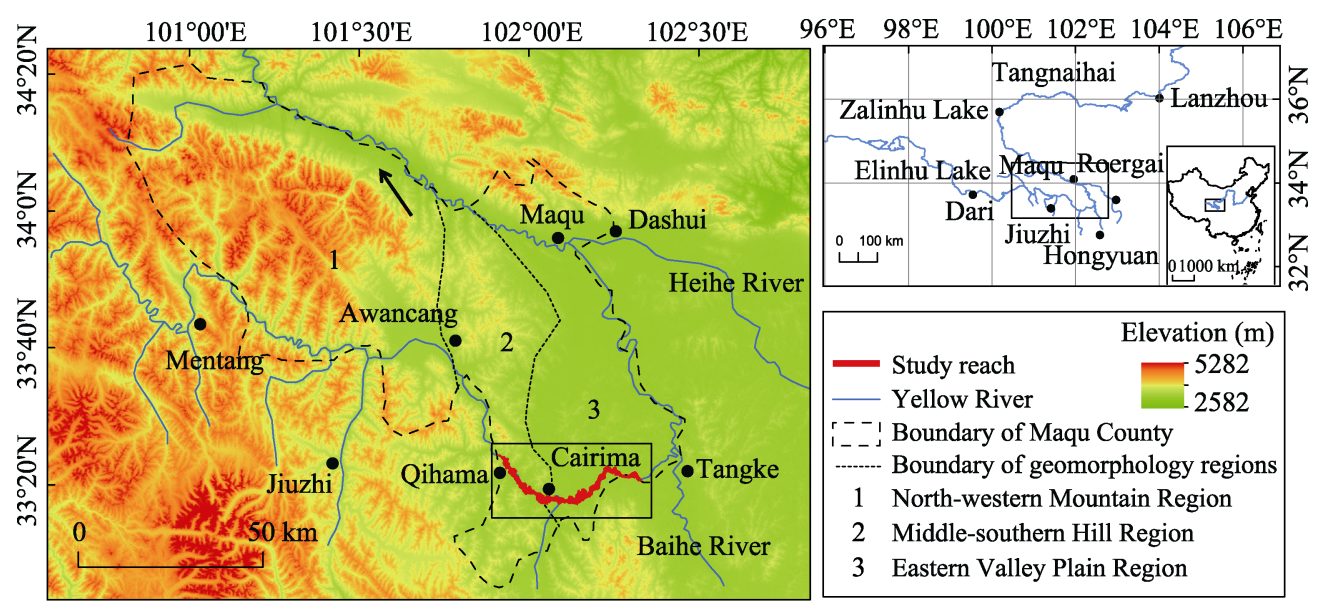

Figure 1 Overview of the location and topography of the study area; the left image is a digital elevation model that includes the tributaries of the Yellow River and the Maqu reach indicated in red

(mean daily discharge of $4320 \mathrm{~m}^{3} / \mathrm{s}$ ) occurred in September 1981, peak flow normally reaches a maximum of $2670 \mathrm{~m}^{3} / \mathrm{s}$ in July and $2870 \mathrm{~m}^{3} / \mathrm{s}$ in September. A minimum monthly mean discharge of $113.72 \mathrm{~m}^{3} / \mathrm{s}$ occurs in February, when ice covers most of the studied reach.

\section{Materials and methods}

Discharge data from the Maqu gauging station were obtained from the Hydrological Yearbook of the Yellow River. High resolution satellite images of the study reach with a resampling resolution of $0.59 \mathrm{~m}$ were extracted from Google Earth using the Google Satellite Map Downloader (Singh et al., 2015). Satellite images (Figure 2a; Images 1, 2, and 3 in Table 1) were acquired from two satellites on three different dates during the flood season (World-

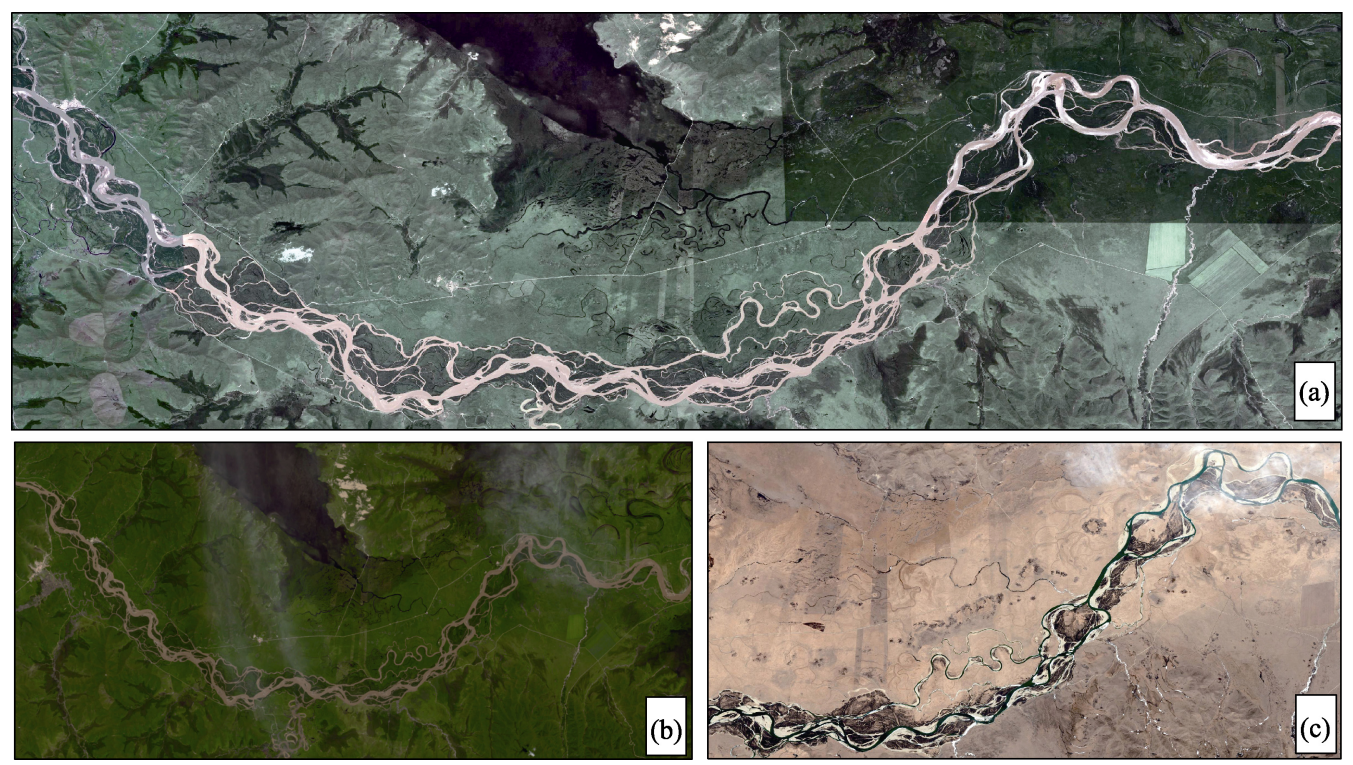

Figure 2 Satellite images of the study reach obtained from Google Earth. (a) Mosaic image of images 1, 2, and 3; (b) image 4, satellite image from Landsat 8; and (c) image 5, satellite image of part of the study reach during low flow 
Table 1 Satellite imagery information

\begin{tabular}{ccccc}
\hline Image & Satellite & Date & Covered reach $(\mathrm{km})$ & Discharge $\left(\mathrm{m}^{3} / \mathrm{s}\right)$ \\
\hline 1 & Worldview-02 & Aug. 27, 2011 & $0-13.34$ & 627 \\
2 & GeoEye-01 & Jul. 29, 2013 & $13.41-45.18$ & 1640 \\
3 & GeoEye-01 & Aug. 1, 2013 & $45.18-64.81$ & 1920 \\
4 & Landsat 8 & Jul. 23, 2013 & $0-64.81$ & 1610 \\
5 & Worldview-02 & Mar. 8, 2011 & $25.25-59.81$ & 113 \\
\hline
\end{tabular}

view-02 on August 27, 2011, GeoEye-01 on July 29, 2013, and August 1, 2013). All satellite imagery information is listed in Table 1. Considering that anastomosing rivers are relatively stable and there were no significant changes in the channel planform over these few years or at different water levels, these satellite images acquired on different dates can be used to quantify the planform of the study reach.

The images were projected to UTM 48N. Based on these images, geomorphologic units were digitized at a scale from 1:1000 to 1:2000 using ArcGIS 10.2. Interchannel wetlands were identified according to the standard proposed in Zanoni et al. (2008); only vegetation patches with vegetation coverage $>75 \%$ were identified. Generally, $90 \%$ of surfaces are usually covered by vegetation in the interchannel wetlands in the study reach. We compared the digitized channel boundary with image 4 (Figure 2b, Landsat 8 on July 23, 2013) and image 5 (Figure 2c, Worldview-02 on March 8, 2011 at low flow), and found no significant differences. Therefore, geomorphologic units extracted from the mosaic image of images 1 , 2 , and 3 can represent the planform characteristics of the study reach.

\section{Results}

\subsection{Micro geomorphologic units and parameters}

To investigate the channel planform, we first defined the typical micro geomorphologic units in the studied reach and chose parameters to describe their characteristics. The micro geomorphologic units (the definitions are listed in Table 2) include river corridor, principal channel, anabranches, interchannel wetlands, and IWCs (Figure 3).

We defined the river corridor, principal channel, and anabranches according to the classification of channels provided in Rice et al. (2009). The principal channel indicates the widest and deepest of all channels; here, all other channels are defined as anabranches. The term interchannel wetlands used here was previously applied in Wang (2000) to a study of anastomosing rivers; the definition is similar to that of established islands presented in Gurnell (2001), which includes vegetated islands developing on gravel bars and those excised from floodplains. The definition of IWCs is similar to compound bar presented in Rice (2009). The difference is that bar-top channels and unvegetated bars in compound bars were considered as channels in IWCs, because they are inundated during flood season, and gravel bars cannot separate channels while interchannel wetlands can.

We chose the area of IWC $\left(S_{\mathrm{u}}\right)$ and number of interchannel wetland in IWC (I) to describe their size characteristics. Parameters, including the ratio of interchannel wetland area to IWC area $(P)$, shoreline density $\left(D_{l}\right.$, the length of total channel shoreline per $\left.\mathrm{km}^{2}\right)$, and 
Table 2 Definition of the micro geomorphologic units in the anastomosing Maqu reach

\begin{tabular}{ll}
\hline \multicolumn{1}{c}{ Micro geomorphologic units } & \multicolumn{1}{c}{ Definition } \\
\hline River corridor & $\begin{array}{l}\text { Area of all geomorphologic units in the anastomosing river, including all channels } \\
\text { and interchannel wetlands } \\
\text { The primary channel in an anastomosing river, which is usually the largest of all } \\
\text { channels and has active water during low flow } \\
\text { Principal channel }\end{array}$ \\
$\begin{array}{l}\text { All channels other than the principal channel } \\
\text { Interchannel wetlands }\end{array}$ & $\begin{array}{l}\text { Vegetated land between channels } \\
\text { Anterchannel wetland clusters } \\
\text { anabranches separating those interchannel wetlands }\end{array}$ \\
\hline
\end{tabular}

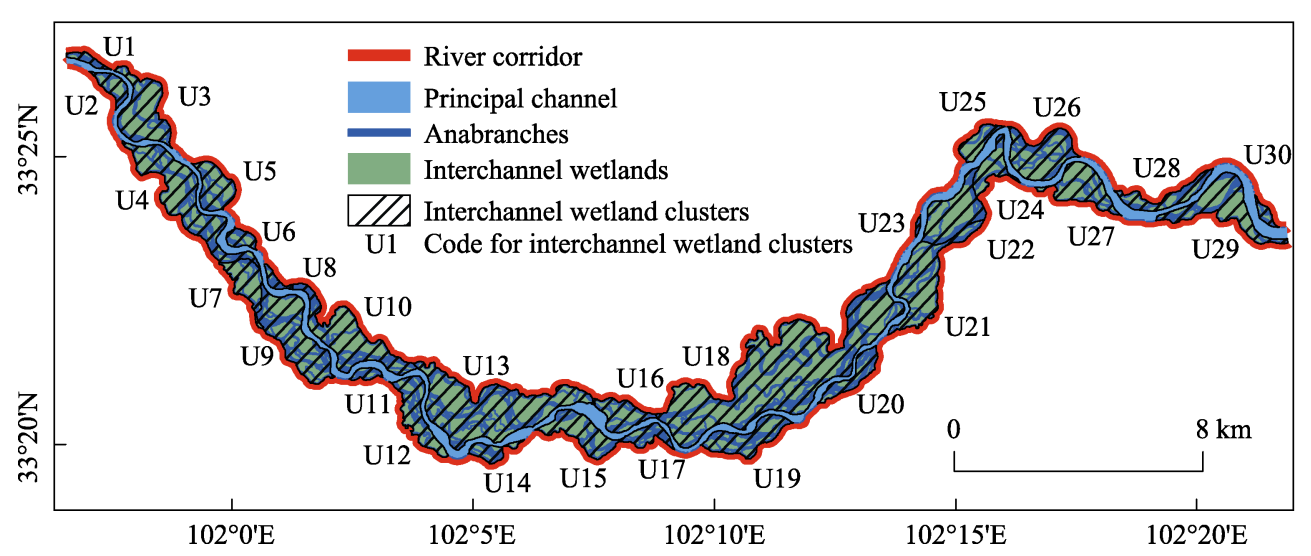

Figure 3 Map of the Maqu reach showing the micro geomorphologic units and interchannel wetland clusters node density $\left(\mathrm{D}_{\mathrm{n}}\right.$, the intersection point of channels per $\left.\mathrm{km}^{2}\right)$ were chosen to analyze the development of IWCs.

The ratio of interchannel wetland area to IWC area $(\mathrm{P})$ is defined as follows:

$$
P=S_{i} / S_{u}
$$

where $S_{i}$ is the sum of the area of interchannel wetlands in an IWC and $S_{u}$ is the area of the IWC.

Shoreline density $\left(\mathrm{D}_{1}\right)$ is calculated according to the following formula:

$$
D_{l}=L_{i} / S_{u}
$$

where $L_{i}$ is the sum of channel shoreline length in an IWC.

Node density $\left(D_{n}\right)$ is calculated as follows:

$$
D_{n}=N / S_{u}
$$

where $N$ is the sum of node numbers in an IWC.

The principal channel and IWCs separated by the principal channel are important geomorphologic units. Despite the few small interchannel wetlands in the principal channel, most are distributed in $30 \mathrm{IWCs}$, which are named $\mathrm{U} 1, \mathrm{U} 2, \ldots$, to $\mathrm{U} 30$ from upstream to downstream. The spatial distribution of IWCs is shown in Figure 3 and their geomorphologic parameters are listed in Table 3.

\subsection{Size distribution of interchannel wetland areas}

There is a significant size difference between the 848 interchannel wetlands in the studied reach. For example, the area of the smallest interchannel wetland is 0.0028 ha, while the 
Table 3 Geomorphologic parameters of the interchannel wetland clusters on the Maqu reach

\begin{tabular}{|c|c|c|c|c|c|c|c|}
\hline Code & $\mathrm{S}_{\mathrm{u}}(\mathrm{ha})$ & I & $\mathrm{P}(\%)$ & $\mathrm{L}_{\mathrm{i}}(\mathrm{km})$ & $\mathrm{D}_{\mathrm{I}}\left(\mathrm{km} / \mathrm{km}^{2}\right)$ & $\mathrm{N}$ & $\mathrm{D}_{\mathrm{n}}\left(\right.$ node $\left./ \mathrm{km}^{2}\right)$ \\
\hline U1 & 28.58 & 5 & 44.89 & 4.32 & 15.13 & 7 & 24.49 \\
\hline $\mathrm{U} 2$ & 63.51 & 16 & 65.40 & 8.08 & 12.72 & 33 & 51.96 \\
\hline $\mathrm{U} 3$ & 250.27 & 22 & 77.32 & 19.50 & 7.79 & 41 & 16.38 \\
\hline U4 & 404.15 & 47 & 73.51 & 43.70 & 10.81 & 83 & 20.54 \\
\hline U5 & 136.88 & 17 & 74.15 & 14.73 & 10.76 & 29 & 21.19 \\
\hline U6 & 44.21 & 15 & 66.02 & 6.93 & 15.67 & 24 & 54.29 \\
\hline U7 & 128.55 & 16 & 81.96 & 13.62 & 10.59 & 28 & 21.78 \\
\hline U8 & 25.31 & 9 & 37.56 & 3.94 & 15.58 & 12 & 47.42 \\
\hline U9 & 345.31 & 53 & 75.80 & 39.65 & 11.48 & 65 & 18.82 \\
\hline U10 & 331.36 & 44 & 71.27 & 32.82 & 9.90 & 64 & 19.31 \\
\hline U11 & 27.77 & 8 & 40.83 & 3.64 & 13.12 & 11 & 39.61 \\
\hline $\mathrm{U} 12$ & 163.57 & 28 & 73.58 & 21.67 & 13.25 & 36 & 22.01 \\
\hline U13 & 672.94 & 85 & 79.12 & 71.11 & 10.57 & 143 & 21.25 \\
\hline U14 & 54.45 & 14 & 50.81 & 7.75 & 14.23 & 28 & 51.42 \\
\hline U15 & 170.26 & 27 & 74.86 & 17.73 & 10.41 & 31 & 18.21 \\
\hline U16 & 119.13 & 15 & 70.07 & 13.97 & 11.73 & 16 & 13.43 \\
\hline U17 & 67.94 & 20 & 50.52 & 10.00 & 14.72 & 31 & 45.63 \\
\hline U18 & 1336.17 & 131 & 79.24 & 110.94 & 8.30 & 202 & 15.12 \\
\hline U19 & 177.93 & 48 & 63.95 & 24.47 & 13.75 & 56 & 31.47 \\
\hline U20 & 95.34 & 41 & 57.09 & 17.20 & 18.04 & 63 & 66.08 \\
\hline U21 & 321.44 & 54 & 78.85 & 35.77 & 11.13 & 67 & 20.84 \\
\hline U22 & 239.77 & 12 & 73.98 & 14.48 & 6.04 & 15 & 6.26 \\
\hline $\mathrm{U} 23$ & 6.46 & 2 & 33.25 & 0.82 & 12.66 & 3 & 46.47 \\
\hline $\mathrm{U} 24$ & 96.14 & 13 & 78.33 & 11.31 & 11.76 & 21 & 21.84 \\
\hline U25 & 70.64 & 4 & 71.70 & 5.92 & 8.37 & 7 & 9.91 \\
\hline U26 & 243.44 & 18 & 71.57 & 22.62 & 9.29 & 32 & 13.15 \\
\hline $\mathrm{U} 27$ & 183.42 & 26 & 83.21 & 18.86 & 10.28 & 45 & 24.53 \\
\hline $\mathrm{U} 28$ & 114.00 & 14 & 55.55 & 11.24 & 9.86 & 22 & 19.30 \\
\hline U29 & 260.51 & 29 & 73.11 & 20.06 & 7.70 & 40 & 15.35 \\
\hline U30 & 25.73 & 4 & 52.71 & 3.54 & 13.77 & 7 & 27.21 \\
\hline
\end{tabular}

largest one is 258.75 ha. According to differences in area, interchannel wetlands were divided into five size ranges: micro ( $<0.1 \mathrm{ha})$, small $(0.1-1 \mathrm{ha})$, middle (1-10 ha), large $(10-100 \mathrm{ha})$, and mega ( $\geqslant 100 \mathrm{ha}$ ) (Table 4). The MRUYR contains 231 micro interchannel wetlands, 284 small interchannel wetlands, 232 middle interchannel wetlands, and 103 large-mega interchannel wetlands. The highest distribution is between the micro and middle sizes. Nevertheless, the large and mega interchannel wetlands have a larger total area. The total area of the 515 micro to small interchannel wetlands is only 117.62 ha, which accounts for $2.55 \%$ of the total area of all interchannel wetlands, while the total area of the 97 large interchannel wetlands is 2988.96 ha, accounting for $64.87 \%$ of the total area of all interchannel wetlands. The total area of four mega interchannel wetlands is 692.67 ha, which accounts for $15.03 \%$ of the total area of all interchannel wetlands (Table 4). 
Table 4 Total number and total area of interchannel wetlands in different size ranges

\begin{tabular}{cccccc}
\hline Area (ha) & Type & $\begin{array}{c}\text { Interchannel } \\
\text { wetlands number }\end{array}$ & $\begin{array}{c}\text { Interchannel wetlands } \\
\text { number frequency (\%) }\end{array}$ & $\begin{array}{c}\text { Total area } \\
\text { (ha) }\end{array}$ & $\begin{array}{c}\text { Total area } \\
\text { frequency }(\%)\end{array}$ \\
\hline$<0.1$ & Micro & 231 & 27.24 & 8.70 & 0.19 \\
$0.1-1$ & Small & 284 & 33.49 & 108.92 & 2.36 \\
$1-10$ & Middle & 232 & 27.36 & 808.19 & 17.54 \\
$10-100$ & Large & 97 & 11.44 & 2988.96 & 64.87 \\
$\geqslant 100$ & Mega & 4 & 0.47 & 692.67 & 15.03 \\
\hline
\end{tabular}

\subsection{Size distribution of interchannel wetland clusters}

Thirty IWCs were found in the studied reach, and their size varies significantly. The largest cluster size is 1336.17 ha, and it contains 1058.75 ha of interchannel wetlands. In contrast, the smallest cluster is only $6.46 \mathrm{ha}$, in which the interchannel wetlands is 2.14 ha. According to differences in area, the IWCs were divided into four size types (Table 5): small $(<100 \mathrm{ha})$, middle (100-200 ha), large (200-500 ha), and mega ( $\geqslant 500$ ha) IWCs.

Table 5 Total area and total number of interchannel wetlands of interchannel wetland clusters with different sizes

\begin{tabular}{cccccccc}
\hline Area (ha) & Type & Number & $\begin{array}{c}\text { Total area } \\
\text { (ha) }\end{array}$ & $\begin{array}{c}\text { Total area } \\
\text { frequency (\%) }\end{array}$ & $\begin{array}{c}\text { Interchannel } \\
\text { wetlands number }\end{array}$ & Number & $\begin{array}{c}\text { Total number } \\
\text { frequency }(\%)\end{array}$ \\
\hline$<10$ & & 1 & 6.46 & 0.10 & $<10$ & 6 & 5.14 \\
$10-50$ & Small & 5 & 151.59 & 2.44 & $10-20$ & 10 & 20.31 \\
$50-100$ & & 6 & 448.02 & 7.22 & $21-50$ & 10 & 36.80 \\
$100-200$ & Middle & 8 & 1193.74 & 19.24 & $51-100$ & 3 & 22.10 \\
$200-500$ & Large & 8 & 2396.24 & 38.62 & $>100$ & 1 & 15.65 \\
$>500$ & Mega & 2 & 2009.11 & 32.38 & & & \\
\hline
\end{tabular}

The total area varies significantly between different types of IWCs (Figure 4). Eighteen middle to mega sized IWCs have a total area of 5599.09 ha $(90.34 \%$ of the total area of all
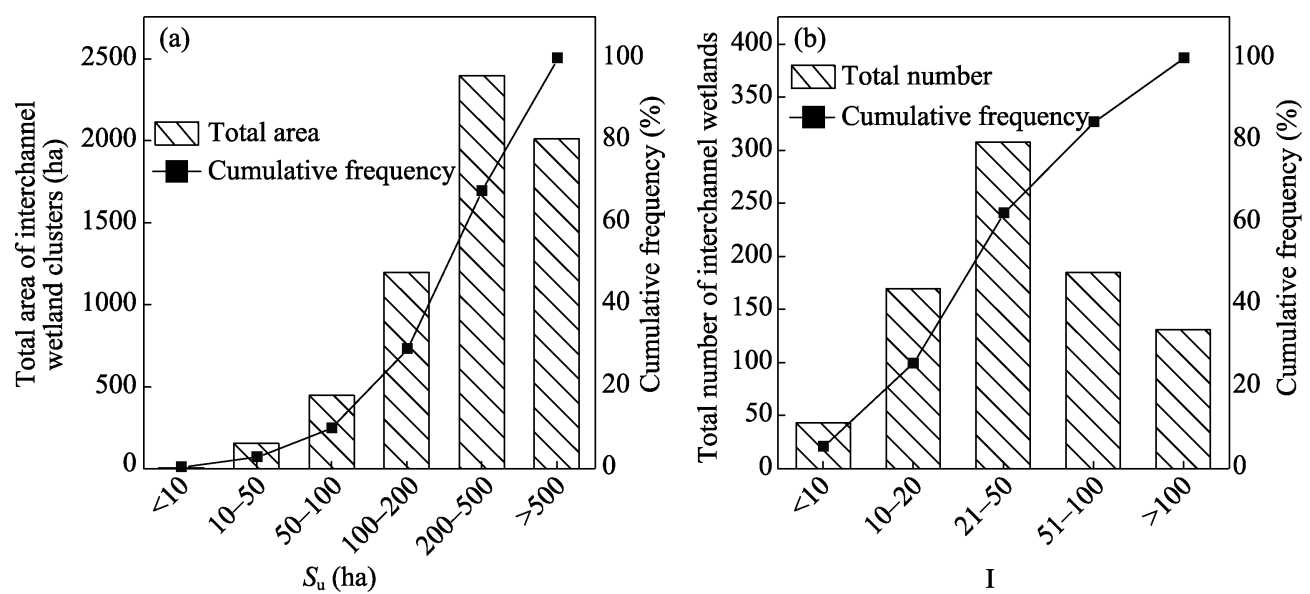

Figure 4 Statistical analysis of interchannel wetlands in interchannel wetland clusters with different areas (a. Total area and cumulative frequency; b. total number of interchannel wetlands and cumulative frequency) 
IWCs). Notably, eight large IWCs have a total area of 2396.24 ha, accounting for $38.62 \%$ of the total area of all IWCs, which is more than any other type of IWCs. In addition, two mega IWCs have a total area of 2009.11 ha, accounting for $32.38 \%$ of the total area. The total number of interchannel wetlands also varies between IWCs. The cluster with the most has 131 interchannel wetlands, while the cluster with the least has only two interchannel wetlands. IWCs containing 21-50 interchannel wetlands occur with the greatest frequency, accounting for $39.67 \%$ of the total number of interchannel wetlands.

\section{Discussion}

\subsection{Relationship between the area of interchannel wetland clusters and geomorpho- logic parameters}

$\mathrm{P}$, the ratio of interchannel wetland area to IWC area, varies between IWCs with different areas. The $P$ value increases with increasing $S_{u}$, the area of the IWC (Figure 5a). When $S_{u}$ is less than 100 ha, $\mathrm{P}$ increases rapidly with increasing $\mathrm{S}_{\mathrm{u}}$, until $\mathrm{P}$ reaches about $70 \%$. When $\mathrm{S}_{\mathrm{u}}$ is between 100 and 500 ha, $\mathrm{P}$ increases slowly from $70 \%$ to about $80 \%$. Noticeably, P reaches a stable value of about $80 \%$ when $\mathrm{S}_{\mathrm{u}}$ is $>500$ ha.

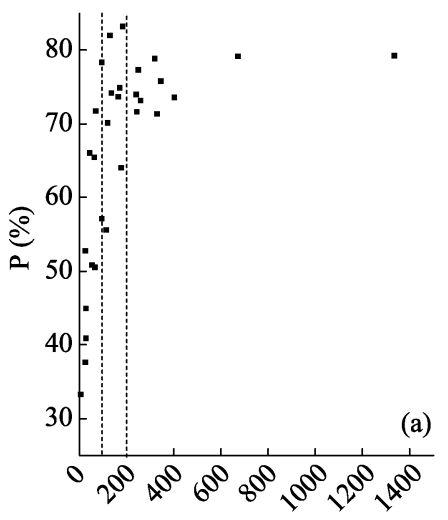

$S_{\mathrm{u}}(\mathrm{ha})$

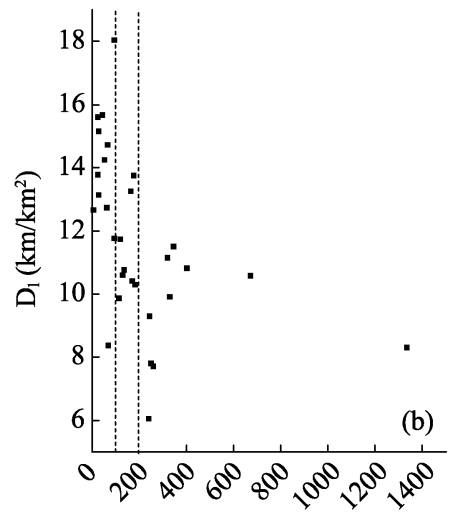

$S_{\mathrm{u}}(\mathrm{ha})$

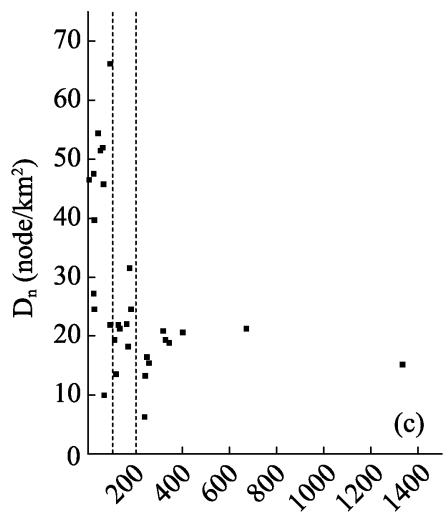

$S_{\mathrm{u}}(\mathrm{ha})$

Figure 5 Relationship between area and other geomorphologic parameters of interchannel wetland clusters, (a) area and ratio of interchannel wetland area to interchannel wetland cluster area, (b) area and shoreline density, and (c) area and node density

This relationship indicates that the development of interchannel wetlands in an IWC reaches a relative stable stage as $\mathrm{P}$ reaches $70 \%$. The upper limit value of $\mathrm{P}$ is $80 \%$, which indicates that the development of interchannel wetlands and anabranches in an IWC has entered the equilibrium stage; the interchannel wetlands occupied in the IWC maintain $80 \%$ and anabranches occupied in the IWC maintain $20 \%$. This is the most stable stage for the development of interchannel wetlands and anabranches.

A relatively stable hydrological condition is one reason that $\mathrm{P}$ increases with increasing $\mathrm{S}_{\mathrm{u}}$. In this condition, the total area of channels maintains a stable value, and the main process for IWC expansion is the growth of interchannel wetlands, which leads to an increase in P. An upper limit for $\mathrm{P}$ suggests that an equilibrium stage between the formation of new channels and extinction of old channels has been reached. Channel capacity reduces with in- 
creasing area of interchannel wetlands, which leads to avulsion and dissection of interchannel wetlands. In this case, the increase in $\mathrm{P}$ is limited.

Shoreline density $\left(D_{1}\right)$ is highly correlated with $S_{u}$ (Figure $5 b$ ). Small interchannel wetlands, $\mathrm{S}_{\mathrm{u}}<100$ ha, have high shoreline density, an average of $13.81 \mathrm{~km} / \mathrm{km}^{2}$. The average $\mathrm{D}_{1}$ value decreases by $17.89 \%$ to $11.33 \mathrm{~km} / \mathrm{km}^{2}$ in the medium-sized IWCs, i.e., $\mathrm{S}_{\mathrm{u}}$ is $100-200$ ha. In large-mega IWCs, $S_{u}>200$ ha, the average $D_{1}$ value further decreases to $9.30 \mathrm{~km} / \mathrm{km}^{2}$, which is $32.64 \%$ less than that of small IWCs (Table 6).

The relationship between node density $\left(D_{n}\right)$ and $S_{u}$ is similar to those between $D_{1}$ and $S_{u}$ (Figure 5c). $D_{n}$ decreases with increasing $S_{u}$. Small IWCs have high node density, averaging 40.53 node $/ \mathrm{km}^{2}$. When $S_{u}$ is $100-200$ ha, the average $D_{n}$ value decreases to 21.49 node $/ \mathrm{km}^{2}$, which is $46.97 \%$ less than that of small IWCs. When $\mathrm{S}_{\mathrm{u}}$ is $>200$ ha, $\mathrm{D}_{\mathrm{n}}$ further decreases to 16.70 node $/ \mathrm{km}^{2}, 58.80 \%$ less than that of small IWCs (Table 6).

Table 6 Interchannel wetland cluster parameters categorized by area

\begin{tabular}{|c|c|c|c|c|c|c|c|c|c|}
\hline \multirow{2}{*}{ Area (ha) } & \multicolumn{3}{|c|}{$\mathrm{P}(\%)$} & \multicolumn{3}{|c|}{$\mathrm{D}_{\mathrm{l}}\left(\mathrm{km} / \mathrm{km}^{2}\right)$} & \multicolumn{3}{|c|}{$\mathrm{D}_{\mathrm{n}}\left(\right.$ node $\left./ \mathrm{km}^{2}\right)$} \\
\hline & Avg. & Min & Max & Avg. & Min & Max & Avg. & Min & Max \\
\hline$<10$ & 33.25 & & & 12.66 & & & 46.47 & & \\
\hline $10-50$ & 48.40 & 37.56 & 66.02 & 14.65 & 13.12 & 15.67 & 38.60 & 24.49 & 54.29 \\
\hline $50-100$ & 62.31 & 50.52 & 78.33 & 13.31 & 8.37 & 18.04 & 41.14 & 9.91 & 66.08 \\
\hline $100-200$ & 72.17 & 55.55 & 83.21 & 11.33 & 9.86 & 13.75 & 21.49 & 13.43 & 31.47 \\
\hline $200-500$ & 74.46 & 71.27 & 78.85 & 9.27 & 6.04 & 11.48 & 16.33 & 6.26 & 20.84 \\
\hline$>500$ & 79.18 & 79.12 & 79.24 & 9.43 & 8.30 & 10.57 & 18.18 & 15.12 & 21.25 \\
\hline
\end{tabular}

Clearly, $S_{u}$ at 100 ha and 200 ha are two important areas during the growth of IWCs. When $S_{u}$ is less than 100 ha, $D_{1}$ and $D_{n}$ maintain high values, when $S_{u}$ is between 100-200 ha, $D_{1}$ and $D_{n}$ decrease significantly, and when $S_{u}$ is $>200$ ha, $D_{1}$ and $D_{n}$ maintain relatively low values.

The difference in development is due to the change in the principal developing process of interchannel wetlands and anabranches. In small IWCs, the increasing number of small anabranches and interchannel wetlands is the main process during growth. Thus, the increasing length and number of anabranches is clear, which leads to high $D_{1}$ and $D_{n}$. In medium-sized IWCs, merging of interchannel wetlands causes the abandonment of some small anabranches. This abandoning process can reduce the rate of increasing number and length of anabranches during the growth of IWCs. Thus, $D_{1}$ and $D_{n}$ are significantly reduced, with $D_{n}$ the most obvious. In large and mega IWCs, the merging of interchannel wetlands and abandoning of channels are more frequent; the development of small interchannel wetlands and anabranches is restricted. Instead, the development of middle and large interchannel wetlands and anabranches is more common. Thus, $D_{1}$ and $D_{n}$ maintain relatively low values.

\subsection{Formation of interchannel wetland clusters}

In the anastomosing MRUYR, the existence of IWCs composed of interchannel wetlands and anabranches is one of its most important characteristics. In this study, we present some preliminary theories to explain the formation of IWCs.

First, the meandering principal channel, as the main conduit for water and sediment 
transportation, plays an important role in the formation of IWCs. The multi-channel network in anastomosing rivers is usually composed of one principal channel and several anabranches. Due to its high stream power, the principal channel controls the change in channel planform in anastomosing rivers. In the studied reach, the main stream of the Yellow River, the controlling function of the principal channel is even clearer than other small to middle size anastomosing reaches. The hydraulic conditions vary on different sides of the meandering principal channel, which causes concentrated deposition in some areas near the principal channel and growth of interchannel wetlands. Large IWCs usually appear on the convex bank of the principal channel, while IWCs are less developed on the concave bank.

Second, the formation of a broad river corridor due to weakening structural control provides enough area to develop IWCs. The valley setting (Yu et al., 2013) is one reason for the channel transformation in MRUYR. Upstream of the reach is a narrow meandering one that is area limited, which essentially prevents the formation of IWCs. When the Yellow River flows from the middle-southern hill region to the eastern valley plain region (Figure 1), the weakening structural control leads to a widening of the river corridor and formation of IWCs, especially at the middle part of the studied reach where two mega IWCs formed.

Third, shrubs and trees growing on channel banks and interchannel wetlands favor the development and preservation of IWCs. Shrubs and trees growing on interchannel wetlands are clearly different vegetation from the alpine meadow covering other areas in this region (Chu et al., 2014). Shrubs and trees stabilize gravel bars (Gurnell et al., 2001) and lead to the formation of new interchannel wetlands or islands, which contribute to the development of IWCs. Furthermore, these shrubs and trees protect interchannel wetlands from lateral erosion (Miller, 1991), especially reducing lateral movement of the principal channel.

\section{Conclusions}

The anastomosing Maqu reach is composed of one meandering principal channel and various interchannel wetlands and anabranches. The interchannel wetlands and anabranches appear in the form of IWCs. Interchannel wetlands ranging in area from small to middle and IWCs in the large or mega area range are the most common in the Maqu reach.

$\mathrm{P}$, the ratio of interchannel wetland area to IWC area, was used to evaluate the characteristic combination of interchannel wetlands and anabranches in this anastomosing river. $\mathrm{P}$ stabilized at $80 \%$, indicating that the development of interchannel wetlands and anabranches in an IWC entered an equilibrium stage. At equilibrium, the formation of new channels and abandonment of old channels were in balance.

Shoreline density $D_{1}$ and node density $D_{n}$ represent the characteristics of anabranches in length and number. In the Maqu reach, $D_{1}$ and $D_{n}$ have a tendency to decrease with increasing $\mathrm{S}_{\mathrm{u}}$ due to diverse evolution processes in the IWCs with different sizes.

There are three primary reasons for the formation of IWCs in the anastomosing Maqu reach: the separating effect of the meandering principal channel, weakened structural control from mountains to valley, and preservation by shrubs and trees growing on interchannel wetlands. 


\section{References}

Abbado D, Slingerland R, Smith N D, 2005. Origin of anastomosis in the upper Columbia River, British Columbia, Canada. In: Blum M D, Marriott S B, Leclair S F. Fluvial Sedimentology VII. Oxford, UK: Blackwell Publishing Ltd., 1-15.

Belletti B, Dufour S, Piégay H, 2015. What is the relative effect of space and time to explain the braided river width and island patterns at a regional scale? River Research and Applications, 31(1): 1-15.

Bertoldi W, Zanoni L, Tubino M, 2009. Planform dynamics of braided rivers. Earth Surface Processes and Landforms, 34(4): 547-557.

Brice J C, 1964. Channel patterns and terraces of the Loup Rivers in Nebraska. U.S. Geological Survey Professional Paper 422-D, Washington DC.

Bryant M, Falk P, Paola C, 1995. Experimental study of avulsion frequency and rate of deposition. Geology, 23(4): 365-368.

Chu L, Huang C, Liu G et al., 2014. Changes in ecological patterns of Maqu alpine wetland in Yellow River Source Area during 2000-2010. Progress in Geography, 33(3): 326-335. (in Chinese)

Church M, Rice S P, 2009. Form and growth of bars in a wandering gravel-bed river. Earth Surface Processes and Landforms, 34(10): 1422-1432.

Friend P F, Sinha R, 1993. Braiding and meandering parameters. In: Best J L, Bristow C S. Braided Rivers. London, UK: Geological Society of London, 75: 105-111.

Gurnell A M, Petts G E, Hannah D M et al., 2001. Riparian vegetation and island formation along the gravel-bed Fiume Tagliamento, Italy. Earth Surface Processes and Landforms, 26(1): 31-62.

Hooke J M, Yorke L, 2011. Channel bar dynamics on multi-decadal timescales in an active meandering river. Earth Surface Processes and Landforms, 36(14): 1910-1928.

Li Z,Wang Z, Pan B et al., 2013a. Analysis of controls upon channel planform at the First Great Bend of the Upper Yellow River, Qinghai-Tibet Plateau. Journal of Geographical Sciences, 23(5): 833-848.

Li Z, Wang Z, Yu G et al., 2013b. River pattern transition and its causes along Maqu reach of Yellow River source region. Journal of Sediment Research, 3: 51-58. (in Chinese)

Liu H, Xu X, Wang J et al., 2012. Type and distribution of aeolian geomorphology at Marqu Region of Upstream Yellow River. Arid Land Geography, 35(3): 348-357. (in Chinese)

Jiang S, 2008. Analysis on variety trend of runoff between Dari and Maqu in the headwater region of Yellow River in the past 50 years. Geographical Research, 27(1): 221-228. (in Chinese)

Jones L S, Schumm S A, 1999. Causes of avulsion: An overview. In: Smith N D, Rogers J. Fluvial Sedimentology VI. Oxford, UK: Blackwell Publishing Ltd., 171-178.

Kidová A, Lehotský M, Rusnák M, 2016. Geomorphic diversity in the braided-wandering Belá River, Slovak Carpathians, as a response to flood variability and environmental changes. Geomorphology, 272: 137-149.

Makaske B, 2001. Anastomosing rivers: A review of their classification, origin and sedimentary products. Earth Science Reviews, 53(3): 149-196.

Makaske B, Smith D G, Berendsen H J A, 2002. Avulsions, channel evolution and floodplain sedimentation rates of the anastomosing upper Columbia River, British Columbia, Canada. Sedimentology, 49(5): 1049-1071.

Makaske B, Smith D G, Berendsen H J A et al., 2009. Hydraulic and sedimentary processes causing anastomosing morphology of the upper Columbia River, British Columbia, Canada. Geomorphology, 111(3/4): 194-205.

Makaske B, Lavooi E, De Haas T et al., 2017. Upstream control of river anastomosis by sediment overloading, upper Columbia River, British Columbia, Canada. Sedimentology, doi: 10.1111/sed.12361.

Miall A D, 1977. A review of the braided river depositional environment. Earth Science Reviews, 13(1): 1-62.

Mikuś P, Wyżga B, Kaczka R J et al., 2013. Islands in a European mountain river: Linkages with large wood deposition, flood flows and plant diversity. Geomorphology, 202: 115-127.

Miller J R, 1991. Development of anastomosing channels in south-central Indiana. Geomorphology, 4: 221-229. 
Osterkamp W R, 1998. Processes of fluvial island formation, with examples from Plum Creek, Colorado and Snake River, Idaho. Wetlands, 18(4): 530-545.

Picco L, Mao L, Rainato R et al., 2014. Medium-term fluvial island evolution in a disturbed gravel-bed river (Piave River, Northeastern Italian Alps). Geografiska Annaler: Series A, Physical Geography, 96(1): 83-97.

Qi D, Li G, 2008. Status, causes and protection counter measures of wetland degradation in Maqu County in the Upper Yellow River. Wetland Science, 5(4): 341-347. (in Chinese)

Rice S P, Church M, Wooldridge C L et al., 2009. Morphology and evolution of bars in a wandering gravel-bed river; lower Fraser river, British Columbia, Canada. Sedimentology, 56(3): 709-736.

Rozo M G, Nogueira A C R, Truckenbrodt W, 2012. The anastomosing pattern and the extensively distributed scroll bars in the middle Amazon River. Earth Surface Processes and Landforms, 37(14): 1471-1488.

Rust B R, 1978. A classification of alluvial channel systems. In: Miall A D. Fluvial Sedimentology. Canada Calgary: Canadian Society of Petroleum Geologists, 187-198.

Schumm S A, 1968. Speculations concerning paleohydrologic controls of terrestrial sedimentation. Geological Society of America Bulletin, 79(11): 1573-1588.

Singh M, Evans D, Friess D et al., 2015. Mapping above-ground biomass in a tropical forest in Cambodia using canopy textures derived from Google Earth. Remote Sensing, 7(5): 5057-5076.

Smith D G, Smith N D, 1980. Sedimentation in anastomosed river systems: examples from alluvial valley near Bannf, Alberta. Journal of Sedimentary Research, 50(1): 157-164.

Tabata K K, Hickin E J, 2003. Interchannel hydraulic geometry and hydraulic efficiency of the anastomosing Columbia River, southeastern British Columbia, Canada. Earth Surface Processes and Landforms, 28(8): 837-852.

Wang S, 2002. Comparison of formation model and channel stability between two different sorts of multiple channel river patterns. Acta Geoscientia Sinica, 23(1): 89-93. (in Chinese)

Wang S, 2003. Architectures, relationships between discharges and width/depth ratios of stream cross profiles, and stream powers of anastomosing rivers. Acta Sedimentologica Sinica, 21(4): 565-570. (in Chinese)

Wang S, 2004. Simulation experiment of anastomosing multiple channel formation. In: Hu C, Tan Y. Proceedings of the Ninth International Symposium on River Sedimentation. Beijing: Tsinghua University Press, 1747-1753.

Wang S, 2008. Analysis of river pattern transformations in the Yellow River basin. Progress in Geography, 27(2): 10-17. (in Chinese)

Wang S, Chen Z, Smith D G, 2005. Anastomosing river system along the middle Yangtze River Basin, Southern China. Catena, 60(2): 147-163.

Wang S, Ni J, Wang G et al., 2004. Hydrological processes of an anastomosing river system on the Zhujiang River delta, China. Journal of Coastal Research, 43(Special Issue): 124-133.

Wang S, Ren M, 1999. A new classification of fluvial rivers according to channel planform and sediment characteristics. Acta Sedimentologica Sinica, 17(2): 240-246. (in Chinese)

Wang S J, Li J S, Yin S P, 2000. Basic characteristics and controlling factors of anastomosing fluvial systems. Chinese Geographical Science, 10(1): 31-38.

Wyrick J R, Klingeman P C, 2011. Proposed fluvial island classification scheme and its use for river restoration. River Research and Applications, 27(7): 814-825.

Yin S, Xie Q, Guan S, 2000. Study on anastomosed river with comparative sedimentology. Acta Sedimentologica Sinica, 18(2): 221-226. (in Chinese)

Yu G, Brierley G, Huang H Q et al., 2014. An environmental gradient of vegetative controls upon channel planform in the source region of the Yangtze and Yellow rivers. Catena, 119: 143-153.

Yu G, Liu L, Li Z et al., 2013. Fluvial diversity in relation to valley setting in the source region of the Yangtze and Yellow rivers. Journal of Geographical Sciences, 23(5): 817-832.

Zanoni L, Gurnell A, Drake N et al., 2008. Island dynamics in a braided river from analysis of historical maps and air photographs. River Research and Applications, 24(8): 1141-1159. 